\title{
Health Status of Widows as a Correlate of Their Participation in Community Development Projects in Nsukka, Enugu State, Nigeria
}

\author{
Matthias U. Agboeze ${ }^{1}$, Ruphina U. Nwachukwu ${ }^{1}$, Michael O. Ugwueze ${ }^{1} \&$ Maryrose N. Agboeze ${ }^{1}$ \\ ${ }^{1}$ Department of Adult Education and Extra-Mural Studies, University of Nigeria, Nsukka, Nigeria \\ Correspondence: Ruphina U. Nwachukwu, Department of Adult Education and Extra-Mural Studies, University \\ of Nigeria, Nsukka, Nigeria. Tel: 234-701-537-8097. E-mail: ruphina.nwachukwu@unn.edu.ng
}

Received: December 25, 2019 Accepted: March 26, 2020 Online Published: May 14, 2020

doi:10.5539/gjhs.v12n7p72 URL: https://doi.org/10.5539/gjhs.v12n7p72

\begin{abstract}
Objectives: This study seeks to examine the health status of widows and investigate its effect on their participation in community development projects.

Methods: A cross-sectional study was conducted on the widows and non-widows in six communities out of the 18 communities in Nsukka local government area of Enugu state, Nigeria from 15 January to 29 March 2019. The respondents were tested clinically based on the following health indices; blood pressure, blood sugar level, malaria parasite and typhoid. The widows were also asked the extent to which their health conditions affect their participation in community development projects.
\end{abstract}

Results: The mean blood pressure level of the widows is $\frac{160.2}{100.4} \mathrm{Mm} / \mathrm{Hg}$ while their mean blood sugar level is $129.8 \mathrm{Mg} / \mathrm{dl} .55 \%$ of the widows tested positive to typhoid while another $53 \%$ tested positive to malaria parasite. Majority (72\%) of the widows revealed that health condition such as poor eye sight; arthritis; rheumatism; high blood pressure; diabetes; malaria; typhoid; cough and ulcer limit their participation in community development projects.

Conclusions: The widows in Nsukka have a poor health status when compared to the non-widows in the region, which to a great extent, limits their participation in the community development projects available to them. Therefore, there is a very strong correlation between the health status of widows in Nsukka and their participation in the community development projects.

Keywords: health status, widows, community development

\section{Introduction}

Health does not just imply the absence of disease or infirmity; it means a condition of complete physical, mental, and social well-being (WHO, 1948). Based on WHO definition of health, social welfare represents an integral component of overall health, since health has a close bearing to the social-economic conditions of man (Anna et al., 2017). Health is said to exist when an individual has the physical, mental, social, and spiritual ability to perform his duties adequately within the environment in which he/she lives (Anna et al., 2017). Therefore, health is an adequate capacity which makes it possible for an individual to perform his/her daily activities. The level of functionality of an individual depends on his/her health status.

Health status is the measurement of the health condition of a person or group of persons against a clear standard; measurement of health status is often done using clear health indicators (WHO, 1984). Health status is the level of wellness or illness of a person or group of persons; in determining the health status of an individual, the presence of biological dysfunction, symptoms, and functional impairment are put into consideration (American Thoracic Society, 2019). Health status of an individual is the level of his health as assessed by the individual or by some objective measures (Medical Dictionary for Health Professions and Nursing, 2019). Nonetheless, to maintain a stable health status, there is need for peace, food, shelter and adequate economic resources (WHO, 1986). However, research evidence has proved that these necessary requirements for the maintenance of stable health condition become more difficult in the state of widowhood, which is often associated with poverty and need in Nigeria (Eboiyehi, 2008).

Widowhood in Nigeria and some other low and middle-income countries are characterized with a high level of 
deprivations (UN Women, 2012). A widow is a woman who lost her husband in death and is yet to be married to another man; on the other hand the condition of having lost a husband or a wife is referred to as widowhood (Foluso, 2011). The various health challenges of widows in Nigeria could be attributed to various factors. Several times, the widows in Nigerian traditional societies are accused of having a hand in the death of their husbands; this accusation has led some of these widows to be subjected to various harmful burial rites and traditions which pose great danger to their physical and psychological health status in order to prove their innocence; worse yet, things are made more difficult for some widows in Nigeria as they are subjected to isolated life, malnutrition and forceful denial of access to the property of their deceased husband (Ethel, 2012; Osun State Widows Survey, 2013; Eboiyehi, 2013).

There has been some disagreement in few studies carried out on the correlation between widowhood and health status. While the studies of (Hughes \& Waite, 2009; Utz, Casert, \& Lund, 2012), found out that transition to widowhood comes with a lot of physical, emotional and mental stress; widows have more symptoms of depression than their married counterparts and subsequently have an increased risk for health challenges such as cancer or a heart attack. The study of Wolinsky and Johnson (1992) found no correlation between widowhood and health status, regardless of how long the widowhood status has lasted. On the other hand, further findings prove that the grief associated with widowhood in addition to taking up the responsibilities left by the deceased spouse often have adverse effects on the psychological and physical well-being of the widow (Rendall, Weden, Favreault, \& Waldron, 2011; Utz et al., 2012). This current study however seeks to find out the correlation between widowhood, their health status and their participation in community development projects in Nsukka local government area, Enugu state, Nigeria.

Community development projects stems from the desire of the community members to improve their present condition; it involves the process whereby the community members identify their needs and improve on them basically through the use of their local resources. Community development is a positive and gradual process of bringing together the resources of a given community with little or no external support from governmental or non-governmental agencies in order to improve the living condition of the community members (Oyebamiji \& Adekola, 2008). Furthermore, community development is an organized movement which mobilizes community members to participate actively in planning and implementation processes of development projects which will positively impact on their welfare (Oyebamiji \& Adekola, 2008). Therefore, community development is an approach which provides a platform for the community members to participate actively in the planning and implementation of developmental projects affecting their lives; thereby enabling them to have a greater level of control over their developmental process.

Commercial Agriculture Development Project (CADP) is a community development project carried out in Nsukka, Enugu state and four other states in Nigeria. Commercial Agriculture Development Project is supported by World Bank and is aimed at improving agricultural production in the affected areas by supporting commercial agriculture production, processing and marketing outputs amongst small and medium scale commercial farmers and agro-processor (CADP, 2009). Furthermore, the community development projects available in Nsukka Local Government Area of Enugu State, Nigeria includes; construction of water borehole, town hall, market square, health centers, churches and schools; also cleaning the community roads, churches and town hall (Omego, 2011).

Nonetheless, inconsistency in the participation of widows in most community development projects was observed in Nsukka, Enugu State, Nigeria. This could be as a result of health challenges which limit their movement from one place to the other; health challenges such as arthritis, rheumatism among others (Mr John Eze, Personal Communication). However, there is a dearth of research evidence on the relationship between the health status of widows in Nsukka, Enugu State, Nigeria and their participation in community development projects.

Therefore, the objective of this study was to assess the health status of widows as a correlate to their participation in community development projects in Nsukka, Enugu State, Nigeria.

\subsection{Research Questions}

Based on the objective of the study, the following research questions were designed:

1. What is the health status of widows in Nsukka Local government area of Enugu state, Nigeria?

2. To what extent does the health status of widows in Nsukka Local government area of Enugu state, Nigeria affect their participation in community development projects? 


\section{Methods}

\subsection{Study Design and Setting}

The study was conducted in Nsukka Local government area of Enugu state, Nigeria. Nsukka has an area of 1,810 $\mathrm{km}^{2}$ and a population of 309,633 from the 2006 Nigerian National census (Enugu State Government, 2019). Nsukka Local government area has eighteen communities- Nsukka Town (the headquarter and the town of University of Nigeria), Obukpa, EhaNdiagu, Umabor, Edem, Ibagwaagu, Ibagwaani, Obimo, Alor Uno, Okpuje, Okutu/Anuka, Lejja, Eha-Alumona, Ede-Oballa, Opi, Opiagu, Okpaligbo and Awka (Ozor, Ozioko, \& Acheampong, 2015).

A cross-sectional study was conducted on 6 communities out of the 18 communities in Nsukka local government area from 15 January to 29 March 2019. The six communities randomly selected for this study are Nsukka town, Obimo, Okpuje, Lejja, Ede-Oballa and Opi.

\subsection{Population and Sample}

The population of the study consists of 3,042 women made up of 1,106 registered widows and 1,936 non-widow members of the Umuada women association (lineage daughters) from the six selected communities in Nsukka local government area (Nsukka LGA, 2019).

Cluster sampling technique was used to determine the sample size of respondents for the study (Wilson, 2010). The 1106 registered widows from the six selected communities were divided into clusters according to their communities - Nsukka town (215), Obimo (186), Okpuje (165), Lejja (158), Ede-Oballa (189), Opi (193); then 10 respondents were randomly selected from each community, making up 60 registered widows used for the study. On the other hand, the 1926 non-widow members of the Umuada women association were also divided into clusters according to their communities - Nsukka town (423), Obimo (311), Okpuje (296), Lejja (269), Ede-Oballa (318), Opi (309); also, 10 respondents were randomly selected from each community, making up 60 non-widow used for the study. Therefore, a final sample size of 120 respondents was used for the study.

\subsection{Data Collection}

\section{Socio-demographic survey}

A structured questionnaire was employed to obtain data on the age, religion, occupation, family size, and educational status. The questionnaire was pretested in Udenu Local government area of Enugu state Nigeria to assess the suitability of the questionnaire regarding the question comprehensibility and language appropriateness. The questionnaire was administered by the researchers on the spot during their meeting with the respondents.

\section{Health status and participation in community development projects}

To determine the health status of widows in Nsukka Local government area of Enugu state, Nigeria, the respondents were tested clinically so as to determine their blood pressure level and blood sugar level; typhoid and malaria parasite and typhoid test were also carried out on the respondents. The widows were separated from the non-widows during the clinical test period; thereafter the results of the widows were compared with that of the non-widows to determine the health status of widows. On the other hand, to determine the extent to which the health status of widows in Nsukka Local government area of Enugu state, Nigeria affect their participation in community development projects, the sampled widows in each of the communities were interviewed.

Each of the widows were interviewed based on the following questions:

- What are the community development projects in Nsukka Local government area of Enugu state, Nigeria available to you?

- To what extent do you participate in these community development projects?

- Does your health condition limit your participation in community development projects?

- What are the health challenges militating against your participation in these community development projects?

\subsection{Data Analysis}

Quantitative and qualitative data analysis was used for the study. Data collected on the age, religion, occupation, family size, educational status of the respondents and the extent to which the health status of widows affect their participation in community development projects in Nsukka Local government area of Enugu state, Nigeria were analyzed qualitatively. While data gotten on the health status of the respondents were analyzed using mean, standard deviation and analysis of variance. 


\section{Results}

\subsection{Demographic Characteristics of Respondents}

Table 1 reveals the demographic characteristics of the widow and non-widow respondents who participated in the study. A total number of 120 respondents (60 widows and 60 non-widows) aged between 30- 60 years were used for the study. Majority of the widow respondents (52\%) were between 50-60 years. Also, majority of the widow respondents (88\%) were Christians, while $12 \%$ were African traditionalists and none were Muslims. Majority of the widow respondents $(45 \%)$ were traders and $52 \%$ have more than 5 family members. Majority of the widow respondents $(85 \%)$ have educational qualification of High school and below. On the other hand, Majority of the non-widow respondents (43\%) were between 50-60 years. Also, majority of the non-widow respondents (92\%) were Christians, while $8 \%$ were African traditionalists and none were Muslims. Majority of the non-widow respondents $(42 \%)$ were traders and 55\% have more than 5 family members. Majority of the non-widow respondents $(78 \%)$ have educational qualification of High school and below. Hence, the difference between the demographic characteristics of the widow and non-widow respondents is not significant. This is evident in table 1 below.

Table 1. Demographic Characteristics of Respondents

\begin{tabular}{|c|c|c|}
\hline \multicolumn{3}{|c|}{ Widows } \\
\hline Variable (s) & Frequency $(\mathrm{N})$ & Percentage (\%) \\
\hline \multicolumn{3}{|l|}{ Age group (years) } \\
\hline $30-39$ & 5 & 8 \\
\hline $40-49$ & 24 & 40 \\
\hline $50-60$ & 31 & 52 \\
\hline Total & 60 & 100 \\
\hline \multicolumn{3}{|l|}{ Religion } \\
\hline Christian & 53 & 88 \\
\hline Muslim & - & - \\
\hline African Traditionalist & 7 & 12 \\
\hline Total & 60 & 100 \\
\hline \multicolumn{3}{|l|}{ Occupation } \\
\hline Trader & 27 & 45 \\
\hline Farmer & 22 & 37 \\
\hline Civil Servant & 6 & 10 \\
\hline Student & 5 & 8 \\
\hline Total & 60 & 100 \\
\hline \multicolumn{3}{|l|}{ Family Size } \\
\hline 5 and below & 29 & 48 \\
\hline More than 5 & 31 & 52 \\
\hline Total & 60 & 100 \\
\hline \multicolumn{3}{|l|}{ Educational status } \\
\hline High School and below & 51 & 85 \\
\hline Above High School & 9 & 15 \\
\hline Total & 60 & 100 \\
\hline \multicolumn{3}{|l|}{ Non- Widows } \\
\hline Variable (s) & Frequency $(\mathrm{N})$ & Percentage (\%) \\
\hline
\end{tabular}




\begin{tabular}{|c|c|c|}
\hline \multicolumn{3}{|l|}{ Age group (years) } \\
\hline $30-39$ & 7 & 12 \\
\hline $40-49$ & 27 & 5 \\
\hline $50-60$ & 26 & 43 \\
\hline Total & 60 & 100 \\
\hline \multicolumn{3}{|l|}{ Religion } \\
\hline Christian & 55 & 92 \\
\hline Muslim & - & - \\
\hline African Traditionalist & 5 & 8 \\
\hline Total & 60 & 100 \\
\hline \multicolumn{3}{|l|}{ Occupation } \\
\hline Trader & 25 & 42 \\
\hline Farmer & 20 & 33 \\
\hline Civil Servant & 8 & 13 \\
\hline Student & 7 & 12 \\
\hline Total & 60 & 100 \\
\hline \multicolumn{3}{|l|}{ Family Size } \\
\hline 5 and below & 27 & 45 \\
\hline More than 5 & 33 & 55 \\
\hline Total & 60 & 100 \\
\hline \multicolumn{3}{|l|}{ Educational status } \\
\hline High School and below & 47 & 78 \\
\hline Above High School & 13 & 22 \\
\hline Total & 60 & 100 \\
\hline
\end{tabular}

\subsection{Health Status of the Widows}

To answer the first research question, data was gotten through a clinical test so as to determine the blood pressure level and blood sugar level of the respondents; faecal occult blood and malaria parasite and typhoid test were also carried out on the respondents. The test data analyzed revealed that the mean blood pressure level of the widows in Nsukka local government of Enugu state, Nigeria is $\frac{160.2}{100.4} \mathrm{~mm} / \mathrm{Hg}$ while that of the non-widows is $\frac{115.5}{75.9} \mathrm{~mm} / \mathrm{Hg}$; the mean blood sugar level of the widows is $129.8 \mathrm{Mg} / \mathrm{dl}$ while that of the non-widows is $85.6 \mathrm{Mg} / \mathrm{dl}$. On the other, $33(55 \%)$ of the widow respondents tested positive to typhoid fever while only $14(23 \%)$ of the non-widow respondents tested positive to typhoid fever; also, $32(53 \%)$ of the widow respondents tested positive to malaria parasite while $18(30 \%)$ of the non-widow respondents tested positive to malaria parasite. Table 2 and 3 below reveals the health status of widows and non-widows in the selected communities in Nsukka, Enugu state, Nigeria.

The ideal blood pressure level is $\frac{120}{80} \mathrm{~mm} / \mathrm{Hg}$. However, for the purpose of this study, blood pressure between $\frac{130}{90} \mathrm{~mm} / \mathrm{Hg}$ to $\frac{110}{70} \mathrm{~mm} / \mathrm{Hg}$ is accepted to be normal. On the other hand, blood sugar level between 70 to 110 $\mathrm{Mg} / \mathrm{dl}$ is accepted to be normal. Hence, tables 2 and 3 revealed that the average blood pressure of widows in Nsukka local government of Enugu state is very high $\left(\frac{160.2}{100.4} \mathrm{~mm} / \mathrm{Hg}\right)$ compared to that of non-widows in the same region $\left(\frac{115.5}{75.9} \mathrm{~mm} / \mathrm{Hg}\right)$; also, the average blood sugar level of widows in Nsukka local government of Enugu state is very high $(129.8 \mathrm{Mg} / \mathrm{dl})$ compared to that of non-widows in the same region $(85.6 \mathrm{Mg} / \mathrm{dl})$. Also, the tables showed that majority of the widows in Nsukka local government of Enugu state have clear signs of Typhoid and malaria parasite in their blood which is different from the non-widows in the same region. Therefore, the health challenges faced by widows in Nsukka local government of Enugu state, Nigeria include high blood pressure, high blood sugar, typhoid and malaria parasite. 
Table 2. Health Status of widows

\begin{tabular}{lllllll}
\hline \multirow{2}{*}{ Community } & Blood Pressure & \multicolumn{1}{c}{ Blood Sugar } & Typhoid & \multicolumn{2}{c}{ Malaria parasite } \\
\cline { 2 - 6 } & Mean & Mean & $\begin{array}{l}\text { Negative } \\
(\%)\end{array}$ & $\begin{array}{l}\text { Positive } \\
(\%)\end{array}$ & $\begin{array}{l}\text { Negative } \\
(\%)\end{array}$ & $\begin{array}{l}\text { Positive } \\
(\%)\end{array}$ \\
\hline Nsukka & $\frac{160.0}{101.5} \mathrm{~mm} / \mathrm{Hg}$ & $132.2 \mathrm{Mg} / \mathrm{dl}$ & 35 & 65 & 70 & 30 \\
Obimo & $\frac{165.8}{100.5} \mathrm{~mm} / \mathrm{Hg}$ & $120.0 \mathrm{Mg} / \mathrm{dl}$ & 60 & 40 & 45 & 55 \\
Okpuje & $\frac{149.3}{93.3} \mathrm{~mm} / \mathrm{Hg}$ & $137.8 \mathrm{Mg} / \mathrm{dl}$ & 45 & 55 & 40 & 60 \\
Lejja & $\frac{160.3}{100.0} \mathrm{~mm} / \mathrm{Hg}$ & $106.2 \mathrm{Mg} / \mathrm{dl}$ & 40 & 60 & 55 & 45 \\
Ede-Oballa & $\frac{159.8}{102.0} \mathrm{~mm} / \mathrm{Hg}$ & $145.8 \mathrm{Mg} / \mathrm{dl}$ & 30 & 70 & 35 & 65 \\
Opi & $\frac{163.5}{105.0} \mathrm{~mm} / \mathrm{Hg}$ & $136.5 \mathrm{Mg} / \mathrm{dl}$ & 60 & 40 & 35 & 65 \\
Total & $\frac{160.2}{100.4} \mathrm{~mm} / \mathrm{Hg}$ & $129.8 \mathrm{Mg} / \mathrm{dl}$ & 45 & 55 & 47 & 53 \\
\hline
\end{tabular}

Table 3. Health Status of non-widows

\begin{tabular}{lllllll}
\hline \multirow{2}{*}{ Community } & Blood Pressure & \multicolumn{1}{c}{ Blood Sugar } & Typhoid & \multicolumn{2}{c}{ Malaria parasite } \\
\cline { 2 - 6 } & Mean & Mean & $\begin{array}{l}\text { Negative } \\
(\%)\end{array}$ & $\begin{array}{l}\text { Positive } \\
(\%)\end{array}$ & $\begin{array}{l}\text { Negative } \\
(\%)\end{array}$ & $\begin{array}{l}\text { Positive } \\
(\%)\end{array}$ \\
\hline Nsukka & $\frac{110.3}{76.3} \mathrm{~mm} / \mathrm{Hg}$ & $80.5 \mathrm{Mg} / \mathrm{dl}$ & 80 & 20 & 68 & 32 \\
Obimo & $\frac{115.5}{78.2} \mathrm{~mm} / \mathrm{Hg}$ & $78.3 \mathrm{Mg} / \mathrm{dl}$ & 67 & 33 & 65 & 35 \\
Okpuje & $\frac{110.5}{70.3} \mathrm{~mm} / \mathrm{Hg}$ & $94.4 \mathrm{Mg} / \mathrm{dl}$ & 79 & 21 & 72 & 28 \\
Lejja & $\frac{125.3}{75.2} \mathrm{~mm} / \mathrm{Hg}$ & $88.9 \mathrm{Mg} / \mathrm{dl}$ & 77 & 23 & 75 & 25 \\
Ede-Oballa & $\frac{109.5}{79.8} \mathrm{~mm} / \mathrm{Hg}$ & $80.4 \mathrm{Mg} / \mathrm{dl}$ & 81 & 19 & 62 & 38 \\
Opi & $\frac{121.6}{75.3} \mathrm{~mm} / \mathrm{Hg}$ & $91.2 \mathrm{Mg} / \mathrm{dl}$ & 78 & 22 & 78 & 22 \\
Total & $\frac{115.5}{75.9} \mathrm{~mm} / \mathrm{Hg}$ & $85.6 \mathrm{Mg} / \mathrm{dl}$ & 77 & 23 & 70 & 30 \\
\hline
\end{tabular}

Relationship between the health status of widows in Nsukka Local government area of Enugu state and their participation in community development projects.

To answer the second research question, the selected widows in Nsukka local government of Enugu state were interviewed. Hence, from the response of the widows in the selected communities, the following findings were made:

- The community development projects available to the widows in Nsukka local government area of Enugu state Nigeria includes: cleaning of market square, town hall, church, schools, hospitals; also, operating co-operative societies, conflict resolution committees; marriage counseling, cultural dance display, public enlightenment movement, maintenance of road, schools, health care center and water borehole; and sweeping of the community roads.

- Majority of the widows (42\%) rarely participate in the above mentioned community development projects while $15 \%$ of them very rarely participate in the community development projects. Also, $26 \%$ of 
the widows in Nsukka local government area often participate in the community development projects while only $17 \%$ of the widows in Nsukka local government area participate in the community development projects very often.

- Majority (72\%) of the widows in Nsukka local government area revealed that their health condition limit their participation in community development projects while the other $28 \%$ of the respondents stated that their health conditions do not affect their participation in community development projects.

- The health challenges militating against the participation of the widows in Nsukka local government area in community development projects includes poor eye sight, arthritis, rheumatism, high blood pressure, diabetes, malaria, typhoid, cough and ulcer. While elaborating on this point, MrsUgwuagbo from Opi community stated that she is unable to participate in sweeping the community road because due to her poor eye sight, she is exposed to various hazards along the road each time she moves out unaccompanied. MrsUgwuoke from Lejja also revealed that she is a long time patient of typhoid; this has made it difficult for her to participate in the construction of water borehole going on in her community because exposure to sun worsens her health condition greatly.

\section{Discussion}

The purpose of the studywas to assess the health status of widows as a correlate to their participation in community development projects in Nsukka, Enugu State, Nigeria. In this study, it was revealed that the widows in Nsukka local government of Enugu state, Nigeria have poor health status; they are challenged with high blood pressure, high blood sugar level, malaria parasite and typhoid. This is often as a result of the grief, mental stress, anxiety, shock and poor economic status associated with widowhood. Widowhood often leads to severe health consequences related to grief and bereavement (Stroebe, Schut, \& Stroebe, 2007). The health status of the widows keeps getting worse as they are forced to live an isolated life and endure poor malnutrition; they are denied access to the wealth and property of their deceased husband (Eboiyehi, 2013).

Also, in the study, the widows identified cleaning of market square, town hall, church, schools, hospitals; maintenance of road, schools, health center and water borehole; sweeping of the community roads; formation of co-operative societies, conflict resolution committees, marriage counseling, cultural dance display, and public enlightenment movements as community development projects available to them. This is in agreement with other research findings which stated that community development projects available to the women (including widows) include; cleaning of the market square, cleaning of community town hall, sanitation exercise, provision rental services, credits and loans to members of the community, resources for the maintenance of road and schools, carrying out intervention measures for the less privileged in the community, public enlightenment and campaigns, information dissemination activities, mobilization of support of community members for project execution, water bore-hole project, community health centre project, community school renovation project (Nwaogwugwu \& Oghenekevwe, 2016; Mbagwu, Mannir, Ewelum, \& Ezema, 2016).

However, the study revealed that despite the availability of these community development projects, majority of the widows rarely participate in them. Also, majority of the widows in Nsukka local government area revealed that poor health condition such as poor eye sight, arthritis, rheumatism, high blood pressure, diabetes, malaria, typhoid, cough and ulcer limit their participation in community development projects. This proves that the health status of the widows in Nsukka local government area affects their participation in community development projects. To a great extent, their poor health status acts as a deterrent to their participation in community development projects available to them. This conforms with a recent research which found out that women with activity limitations were three times more likely to be widowed; most of women with activity limitations attributed them to disease or illness; also, among people with activity limitations, 9 in 10 women (91\%) had been diagnosed with at least one chronic health problem such as arthritis, back problems, high blood pressure, depression and dysthymia (Crompton, 2011).

\subsection{Limitation}

The study had few limitations. First, due to the difficulty encountered in having older women (widows and non-widows) between the ages of 75 and above to join in the meeting place for focus group discussion, the younger women below the age of 75 were used for the study. The researchers also had to convey the widows to the meeting point using their personal resources. Second, some of the widows were not literate enough to understand questions asked in English or central Igbo language clearly; therefore, the researchers had to employ translators who could be able to translate to the widows in their native language. 


\section{Conclusion}

Widowhood comes along with several health challenges; this is mostly as a result of depression and increased anxiety after the loss of a spouse. The living condition and environmental factors such as living in swampy areas also contribute to the poor health conditions of widows. The widows also have a high chance of relapsing into inactivity, thereby distancing themselves from various community development projects available to them. Therefore, this study suggests that the widows are assisted in maintaining a healthier health condition through the provision of aids from governmental and non-governmental organizations so as to enable them maintain a healthier condition and participate more in community development projects.

\section{Acknowledgements}

The authors acknowledge with gratitude MrsEzugwuModester (Medical Laboratory Scientist, University of Nigeria Medical center) and her team of experts, who carried out the clinical test on the respondents. Also to the respondents and the translators who made it easier for the data collection process to be successful.

\section{Ethics approval and consent to participate}

Verbal consent was obtained from all participants; written consent was not required for the following reasons: (1) all the data were analyzed anonymously; therefore, the privacy and personal identity of all the participants were protected. (2) all the blood samples were not and will not be used for any other purpose. Therefore, the waiver for written consent will not pose any risks to the rights and health of the participants. The researchers sought for and got approval from the Research and Ethics Committee of the Faculty of Education, University of Nigeria Nsukka. The approval to carry out the research was accompanied by a supporting letter. The unique approval number for the study is REC/FE/2019/000012.

\section{Competing Interests Statement}

The authors have no conflicts of interest.

\section{References}

American Thoracic Society. (2019). Health status, health perceptions. https://qol.thoracic.org/sections/key-concepts/health-status-health-perceptions.html

Anna, L. S., Doncho, D., Nina, J. K., \& Srecko, G. (2017). Concepts and definitions of health and health related values in the knowledge landscapes of the digital society. Croat Med J., (58). 431-5. https://doi.org/10.3325/cmj.2017.58.431

Chen, J. H., Bierhals, A. J.,Prigerson, H. G., Kasl, S. V., Mazure, C. M., \& Jacobs, S. (1999). Gender differences in the effects of bereavement related psychological distress in health outcomes. Psychological Medicine, 29, 367-380. https://doi.org/10.1017/S0033291798008137

Commercial Agriculture Development Project (CADP) working documents (2009). Project Appraisal Documents (PAD) and Project Implementation Manual (PIM).

Crompton, S. (2011). Women with Activity Limitations. Women in Canada: A Gender-based Statistical Report. Ministry of Industry.

Deere, C. D., \& Doss, C. (2006). The gender asset gap: What do we know and why does it matter? Feminist Economics, 12(1), 1-50. https://doi.org/10.1080/13545700500508056

Eboiyehi, F. A. (2008). Care and Support for the Aged among the Esan of Edo State, Nigeria (Unpublished PhD thesis, Department of Sociology, University of Ibadan, Nigeria).

Eboiyehi, F. A. (2013). Elderly widows and poverty: Empirical evidence from rural Nigeria. The Journal of International Social Research, 6(26).

Enugu State Government Official website: http://www.enugustate.gov.ng/nsukkaLGA.php

Ethel, E. I. (2012). The inhuman treatment of widows in african communities. Current Research Journal of Social Sciences, 4(1), 6-11.

Foluso, A. F. (2011). Gender based sexual violence among Nigerian widows: Implication for HIV transmission. Current Research Journal of Social Sciences, 3(2), 139-145.

Hughes, M. E., \& Waite, L. J. (2009). Marital biography and health at mid-life. Journal of Health and Social Behavior, 50, 344-358. https://doi.org/10.1177/002214650905000307

Mbagwu, F. O., Mannir, A., Ewelum, J. N., \& Ezema, M. C. (2016). Youth involvement in self-help community 
development projects (SHCDPs) in Nsukka, Enugu State, Nigeria. Review of European Studies, 8(4), 240-251. https://doi.org/10.5539/res.v8n4p240

Medical Dictionary for Health Professions and Nursing. (2012). Health Sta-tus. https://medical-dictionary.thefreedictionary.com/health+status.

Nsukka Local Government. (2019). Document on Non Governmental Organizations.Nsukka Local Government area secretariat.

Nwaogwugwu, O. N., \& Oghenekevwe, M. (2016). Socio-economic factors affecting women participation in community development activities in Uvwie Local Government Area of Delta State, Nigeria: Implication for Agricultural Transformation Agenda. PAT, 12(1), 27-35.

Oberteuffer, D. (1960). School Health Education (3rd ed.). New York: Harper and Brothers.

Omego, J. O. (2011). Assessment of women's participation in community development projects in Nsukka Local Government Area of Enugu State (Masters Dissertation. Department of Adult Education and Extra-Mural Studies, University of Nigeria Nsukka).

Osun State Widows Survey. (2013). A Survey of Widows Vulnerability in the State of Osun: An Action Oriented Study.

Oyebamiji, M. A., \& Adekola, G. (2008). Fundamentals of Community Development in Nigeria. Port Harcourt: University of Port Harcourt Press.

Ozor, N., Ozioko, R., \& Acheampong, E. (2015). Rural-Urban interdependence in food systems in Nsukka Local Government Area of Enugu State, Nigeria. Journal of Agricultural Extension, 19(2), 157-183. https://doi.org/10.4314/jae.v19i2.14

Rendall, M. S., Weden, M. M., Favreault, M. M., \& Waldron, H. (2011). The protective effect of marriage for survival: A review and update. Demography, 48, 481-506. https://doi.org/10.1007/s13524-011-0032-5

Stroebe, M., Schut, H., \& Stroebe, W. (2007). Health outcomes of bereavement. The Lancet, 370(9603), 1960-73. https://doi.org/10.1016/S0140-6736(07)61816-9

UN Women. UN Women South Asia Sub Regional Office. Delhi: 2012. From exclusion to empowerment: a baseline assessment of UN Women's Programme for the Empowerment of Widows and their Coalitions.

Utz, R. L., Caserta, M., \& Lund, D. (2012). Grief, depressive symptoms, and physical health among recently bereaved spouses. The Gerontologist, 52, 460-471. https://doi.org/10.1093/geront/gnr110

WHO. (1948). World Health Organization Constitution.

WHO. (1984). Glossary of Terms used in Health for All series N9. WHO, Geneva.

WHO. (1986). Ottawa Charter for Health Promotion. WHO/HPR/HEP/95.1. WHO, Geneva. https://doi.org/10.1093/heapro/1.4.405

Wilson, J. (2010). Essentials of business research: a guide to doing your research project. Sage Publication.

Wolinsky, F. D., \& Johnson, R. J. (1992). Perceived health status and mortality among older men and women. Journal of Gerontology, 47(6). 304-12.https://doi.org/10.1093/geronj/47.6.S304

\section{Copyrights}

Copyright for this article is retained by the author(s), with first publication rights granted to the journal.

This is an open-access article distributed under the terms and conditions of the Creative Commons Attribution license (http://creativecommons.org/licenses/by/4.0/). 